ISSN: 2302-8556

E-Jurnal Akuntansi Universitas Udayana

Vol.25.2.November (2018): 934-958

DOI: https://doi.org/10.24843/EJA.2018.v25.i02.p05

\title{
Pengaruh Tipe Industri, Kepemilikan Saham Pemerintah, Profitabilitas Terhadap Sustainability Report
}

\section{K. Baba Adiatma ${ }^{1}$ \\ I Ketut Suryanawa ${ }^{2}$}

${ }^{1}$ Fakultas Ekonomi dan Bisnis Universitas Udayana (Unud), Bali, Indonesia email: guz_adiatma95@yahoo.co.id./ Telp: 082147297061

${ }^{2}$ Fakultas Ekonomi dan Bisnis Universitas Udayana (Unud), Bali, Indonesia

\begin{abstract}
ABSTRAK
Perusahaan yang beraktivitas bisnis tanpa menghiraukan tanggung jawab sosial dan lingkungan menyebabkan kerusakan terhadap lingkungan dan sosial perusahaan. Sustainability report menjadi alat kendali untuk risiko keberlanjutan yang dapat memberikan informasi ekonomi, lingungan dan sosial perusahaan. Perusahaan yang menerbitkan sustainability reportmasih sedikit, hal ini mengindikasikan bahwa terdapat faktor yang memengaruhi sustainability report. Tujuan penelitian ini untuk mengetahui apakah tipe industri, kepemilikan saham pemerintah, profitabilitas berpengaruh terhadap sustainability report. Seluruh perusahaan yang terdaftar di BEI tahun 2013-2016 menjadi populasi penelitian ini dan sampel diambil dengan kriteria tertentu. Sampel terdiri dari 12 perusahaan yang diamati selama empat tahun sehingga jumlah sampel sebanyak 48. Data penelitian diperoleh dari laporan tahunan masing-masing perusahaan. Metode yang cocok untuk menganalisis penelitian ini adalah regresi linier berganda. Dari analisis diperoleh bahwa tipe industri berpengaruh positif terhadap sustainability report, sedangkan kepemilikan saham pemerintah dan profitabilitas tidak berpengaruh terhadap sustainability report.
\end{abstract}

Kata Kunci: Tipe industri, kepemilikan saham pemerintah, profitabilitas.

\begin{abstract}
Companies that move business regardless of social and environmental responsibility cause damage to the company's environment and social. Sustainability report is a control tool for sustainability risk that can provide economic, corporate and social information. Companies that publish sustainability reports are still small, indicating that there are factors affecting sustainability reports. The purpose of this study to determine whether the type of industry, government stock ownership, profitability affect sustainability report. The population of this study are all companies listed on the BEI in 2013-2016. Sampling using purposive sampling method. The sample consists of 12 companies observed for four years so that the number of samples is 48. The research data is obtained from the annual report of each company. The suitable method for analyzing this research is multiple linear regression. From the analysis, it is found that industry type has a positive effect on sustainability report, while government ownership and profitability have no effect on sustainability report.
\end{abstract}

Keywords: Industry type, government share ownership, profitability. 
K. Baba Adiatma dan I Ketut Suryanawa. Pengaruh...

\section{PENDAHULUAN}

Perusahaan bisnis mulai menyadari untuk menerapkan prinsip ekonomi berkelanjutan yang mengarah pada kegiatan ekonomi, lingkungan, sosial perusahaan(Ahmad, 2014). Kesadaran perusahaan untuk tidak saja fokus terhadap laba material, namun harus mengedepankan kontribusi terhadap peningkatan kesejahteraan (Chwastiak, 1999). Dampak dari perusahaan yang tidak menerapkan prinsip ekonomi berkelanjutan menjerumuskan perusahaan kepada penurunan kondisi sosial dan kerusakan lingkungan, seperti krisis kekeringan di Klaten yang diduga akibat eksploitasi sumber air oleh PT Tirta Investama, penutupan tambang pasir besi PT Aneka Tambang di Cilacap (Susanto \& Tarigan, 2013).

Stakeholder yang peka terhadap peningkatan risiko keberlanjutan dari perusahaan bisnis mulai menuntut akan adanya metode pengendalian untuk meminimalkan risiko tersebut (Jose \& Lee, 2007). Stakeholder telah tertarik untuk mempertimbangkan informasi sosial dalam laporan tahunan perusahaan. Metode tersebut harus mampu memuat informasi mengenai dampak ekonomi, sosial serta lingkungan perusahaan, prinsip tersebut dinamakan Tripple $-P$ Bottom Line (Elkington, 1997). Metode pengendalian tersebut dianggap perlu sehingga munculah sustainability report sebagai laporan yang memenuhi prinsip tersebut.

Kegiatan pengukuran, menginformasikan secara akuntabilitas kinerja manajemen guna menyambung komunikasi tujuan pembangunan berkelanjutan perusahaan kepada stakeholder. Kandungan informasi dalam sustainability report 
berisi tentang kinerja keuangan maupun non keuangan perusahaan yang membuat pertumbuhan berkelanjutan perusahaan (Elkington, 1998).

Perusahaan termotivasi untuk melaporkan sustainability report yang menjadi jembatan informasi antara pihak manajamen dan pihak stakeholder perusahaan (Finch, 2005). Selain itu motivasi lain perusahaan adalah menciptakan image baik perusahaan meski perlu mengorbankan sumber daya untuk aktivitas tersebut (Gray, Owen, \& Maunders, 1988). Bahkan Moir (2009) mengatakan bahwa terlepas dari didapatnya keuntungan dari informasi sosial perusahaan, perusahaan terkait atau tidak dalam menciptakan masalah sosial, perusahaan harus membantu memecahkan masalah sosial yang ada dalam lingkungannya.

(Sanditoso \& Chandra, 2012) menyebutkan dalam penelitiannya bahwa terdapat sorotan dari pemerintah mengenai pembangunan ekonomi berkelanjutan perusahaan dengan terbitnyaPasal 74, UU No 40 Tahun 2007 menyatakan Perseroan yang menjalankan kegiatan usahanya di bidang dan/atau berkaitan dengan sumber daya alam wajib melaksanakan Tanggung Jawab Sosial dan Lingkungan (TJSL).

Aturan terbaru Nomor 51/POJK.03/2017 tentang penerapan keuangan berkelanjutan bagi lembaga jasa keuangan, emiten, dan perusahaan publik telah mewajibkan seluruh perusahaan yang terdaftar di BEI untuk mengungkapkan sustainability report pada tahun 2019. Namun emiten yang memublikasi sustainability report masih rendah. Tercatat tahun 2016, hanya sekitar sembilan persen emiten yang melakukan publikasi laporan ini. Rendahnya tingkat publikasi 
K. Baba Adiatma dan I Ketut Suryanawa. Pengaruh...

sustainability report mengindikasikan bahwa terdapat faktor yang memengaruhi perusahaan untuk melakukan publikasi sustainability report.

Faktor penting yakni ciri khas perusahaan, salah satunya adalah tipe industri. Tipe industri memiliki dua tipe, tipe pertama adalah tipe high profile dengan ciri khas mempunyai risiko tinggi dalam politik dan kompetisi yang ketat sedangkan tipe kedua adalah tipe low profile dengan ciri khas yang sebaliknya (Roberts, 1992). Dapat diartikan perusahaan (high) yang bersinggungan dengan pihak luas tentu dengan kesalahan yang terjadi akan menjadi sorotan pihak luas. Oleh sebab itu diperkirakan perusahaan akan menyampaikan informasi tentang pelaksanaan tanggung jawab ekonomi, sosial, lingkungan melalui sustainability reportse hingga menimbulkan kepercayaan stakeholder.

Kepemilikan saham pemerintah merupakan seluruh saham yang dipunyai oleh pemerintah. Sebagai pemegang saham, pemerintah memiliki hak untuk mengendalikan pergerakan bisnis yang dilakukan manajemen sehingga selaras dengan kebijakan pemerintah (Amran \& Devi, 2008).

Pemerintah sebagai pembuat kebijakan (Undang - Undang) akan secara bijak mengambil jalan yang terbaik demi kesejahteraan bersama. Sebagai salah satu pemegang saham, pemerintah tentu akan bertindak sejalan dengan kebijakan yang dikeluarkannya dalam memengaruhi kebijakan manajemen perusahaan. Maka dari itu publikasisustainability report menjadi keharusan dalam kebijakan manajeman perusahaan.

Profitabilitas merupakan faktor penting dalam memengaruhi sustainability report. Ketika perusahaan mendapat keuntungan yang rendah maka manajemen 
akan menurunkan biaya sosial dengan mengurangi informasi yang ada dalam sustainability reportdemi menjaga hubungan dengan para stakeholder dengan begitu stakeholder akan merasa bahwa modal yang mereka percayakan kepada pihak manajemen telah dikelola dengan bijaksana oleh manajemen. Sebaliknya jika keuntungan perusahaan tinggi maka manajemen akan berupaya menjaga tingkat keuntungan tersebut bahkan ingin meningkatkanya, maka dari itu manajemen mengeluarkan biaya sosial untuk meningkatkan image sehingga membentuk loyalitas konsumen. Pendapat tersebut sejalan dengan penemuan Prihandono (2010), Rahajeng (2010), Fahrizqi (2010), mereka menemukan bahwa semakin tinggi tingkat profitabilitas perusahaan maka semakin tinggi pula pengungkapan tanggung jawab sosial perusahaan.

Dahlia (2010) berpendapat bahwa semakin besar profit yang diperoleh suatu perusahaan diharapkan memberikan transparansi laporan yang besar pula. Pernyataan tersebut diperkuat oleh Untari (2010) yang menyatakan bahwa semakin besar profitabilitas suatu perusahaan akan mengungkapkan tanggung jawab sosial yang lebih besar karena sorotan yang besar dari masyarakat.

Kemampuan penghasilan laba usaha dari kegiatan bisnis perusahaan merupakan tingkat profitabilitas perusahaan (Caroline dan Agaton, 2010). Alat ukur yang dapat mengukur seberapa kuat perusahaan untuk menghasilkan keuntungan untuk pemegang sahamnya disebut return on equity. Keuntungan dari operasi perusahaan yang dihasilkan dari modal yang diberikan oleh pemegang saham perusahaan. Jika tingkat ROE tinggi maka keuntungan tinggi pula untuk pemegang sahamnya, namun jika kerugian yang diperoleh oleh perusahaan maka 
K. Baba Adiatma dan I Ketut Suryanawa. Pengaruh...

pemegang saham perusahaanlah yang juga menanggung kerugian yang dihasilkan oleh perusahaan.

Berdasarkan uraian permasalahan diatas dibutuhkan penelitian terhadap hubungan bisnis dan masyarakat dalam rangka untuk mendefinisikan kembali peran dan tugas perusahaan dari murni ekonomi murni menuju ke institusi ekonomi sosial (Mangos \& Lewis, 1995). Maka dari itu penelitian ini akan menguji pengaruhtipe industri, kepemilikan saham pemerintah, profitabilitas terhadap sustainability report. Perbedaan dengan penelitian sebelumnya adalah pada variabel, waktu penelitian, sampel. Sedangkan variabel yang diadopsi adalah profitabilitas, kepemilikan saham pemerintah dan tipe industri. Selain itu, sampel yang digunakan dalam penelitian ini adalah perusahaan yang terdaftar di Bursa Efek Indonesia dengan periode tahun penelitian 2013-2016.

Penelitian ini bertujuan untuk mengetahui pengaruh tipe industri, kepemilikan saham pemerintah, profitabilitas terhadap sustainability report. Penelitian ini akan berkontribusi pada pengembangan akuntansi keuangan, terutama mengenai bagaimana tipe industri, kepemilikan saham pemerintah, profitabilitas dapat berpengaruh terhadap sustainability reportserta menjadi bahan pertimbangan untuk membuat kebijakan dalam penerapan prinsip pembangunan ekonomi berkelanjutan dan publikasi laporan tersebut.

Stakeholder merupakan semua pihak yang memberi pengaruh atau mendapat pengaruh oleh suatu prestasi dari kinerja organisasi (Freeman, 2004). Tujuan dari manajemen stakeholder adalah untuk merancang metode untuk mengelola berbagai kelompok dan hubungan yang dihasilkan dengan cara 
strategis (Freeman \& McVea, 2001). Dukungan stakeholder sangat dicari perusahaan karena dapat memengaruhi kelangsungan hidup perusahaan. Demi mendapat dukungan tersebut maka informasi pembangunan ekonomi berkelanjutan menjadi bagian dialog antara pihak manajemen dengan stakeholdernya (Gray, Kouhy, \& Lavers, 1995). Stakeholder dapat dibagi menjadi dua berdasarkan karakteristiknya yaitu stakeholder primer dan stakeholder sekunder (Clarkson, 1995).

Teori legitimasi merupakan teori yang menyatakan bahwa perusahaan berupaya dalam kegiatan operasionalnya untuk selaras dengan norma - norma yang berlaku bagi masyarakat setempat (Patten, 1991). Hal ini dilakukan untuk penerimaan aktivitas perusahaan oleh pihak eksternal (Deegan, 2002). Usaha untuk berkegiatan selaras dengan norma-norma yang berlaku dalam masyarakat di lingkungan perusahaan dapat menciptakan situasi untuk mendukung kegiatan operasional perusahaan dari pihak eksternal sehingga terciptanya suatu imageyang baik dimata pihak eksternal.

Tipe Industri merupakan karakter yang dimiliki industri. Penelitian ini menggolongkan tipe industri menjadi 2, yakni high-profile dan low-profile. Perusahaan yang bertipe high-profile akan bersinggungan dengan kepentingan pihak luas sehingga kesalahan yang dilakukan akan menjadi masalah bagi banyak pihak dengan begitu tentu perusahaan akan menjadi sorotan. Perusahaan harus menjaga hubungannya dengan stakeholder untuk memastikan bahwa perusahaan akan berjalan secara berkelanjutan. Hubungan tersebut dapat dijaga dengan pengungkapan tanggung jawab terhadap ekonomi, sosial, lingkungan dan 
K. Baba Adiatma dan I Ketut Suryanawa. Pengaruh...

stakeholder yang tertuang dalam sustainability report. Biaya sosial yang terungkapkan akan membentuk kepercayaan stakeholder dan mendapat legitimasi dari masyarakat. Citra baik perusahaan menjadi hal yang baik demi masa depan perusahaan sehingga dapat diambil hipotesis sebagai berikut:

$\mathrm{H}_{1}$ : Tipe industri berpengaruh positif terhadap sustainability report

Jumlah saham yang dimiliki pemerintah akan berpengaruh terhadap kebijakan yang diterapkan oleh perusahaan. Pemerintah telah mengeluarkan kebijakan mengenai penerapan laporan sustainability report. Melalui BAPEPAMLK yang sekarang ini bernama OJK (Otoritas Jasa Keuangan) pemerintah mengeluarkan Pasal 74,UU No 40 Tahun 2007 tentang Perseroan Terbatas yang isinya Perseroan yang menjalankan kegiatan usahanya di bidang dan/atau berkaitan dengan sumber daya alam wajib melaksanakan Tanggung Jawab Sosial dan Lingkungan (TJSL). Maka dari itu sebagai pemegang saham perusahaan, pemerintah akan memengaruhi kebijakan manajemen perusahaan agar sesuai dengan kebijakan pemerintah. Pemerintah menghendaki untuk melaksanakan pembangunan ekonomi berkelanjutan sesuai dengan aturan yang telah diterbitkan oleh pemerintah. Dari uraian di atas maka dapat diambil hipotesis sebagai berikut: $\mathrm{H}_{2}$ : Kepemilikan saham pemerintah berpengaruh positif terhadap sustainability report.

Profitabilitas merupakan tingkat keuntungan yang diperoleh perusahaan. Ketika perusahaan memperoleh tingkat keuntungan yang tinggi maka keuntungan bagi pemegang sahampun juga tinggi, pemegang saham akan merasa tidak keberatan bila biaya sosial akan dibebankan akan oleh perusahaan. Reaksi berbeda terjadi jika tingkat keuntungan yang didapat perusahaan rendah, pemegang saham 
tidak akan puas dengan hal tersebut dan tentu memengaruhi kebijakan manajemen untuk meminimalkan biaya sosialnya dalam pengungungkapan sustainability report yang tentunya akan memengaruhi luas pengungkapan sustainability report. Manajemen akan berusaha menjaga hubungan baik dengan pemegang saham dengan meminimalkan biaya sosialnya sehingga keuntungan pemegang saham tidak turun lagi. Jawaban sementara yang dapat diambil dalam penelitian ini adalah:

$\mathrm{H}_{3}$ : Profitabilitas berpengaruh positif terhadap sustainability report

\section{METODE PENELITIAN}

Sustainability report menjadi variabel yang dipengaruhi, sedangkan variabel yang mempengaruhi dalam penelitian ini adalah tipe industri, kepemilikan saham pemerintah, profitabilitas. Seluruh perusahaan yang terdaftar di BEI antara tahun 2013-2016 menjadi populasi dalam penelitian.

Purposive sampling merupakan metode dalam pengambilan sampel penelitian dengan kriteria sebagai berikut: a)sampel merupakan perusahaan yang terdaftar di BEI selama tahun 2013-2016. b) perusahaan yang mempublikasikan sustainability report antara tahun 2013-2016. c) terdapat kepemilikan saham pemerintah dalam perusahaan tersebut.

Laporan Tahunan yang terdapat di Bursa Efek Indonesia antara tahun 20132016 merupakan data yang akan diteliti. Penulis menggunakan periode tahun tersebut sebagai waktu penelitian karena Laporan tahun 2013-2016 merupakan data terbaru yang diperoleh dari Bursa Efek Indonesia. 
Statistik deskriptif adalah statistik yang tingkat pekerjaannya mencakup cara-cara pengumpulan, menyusun atau mengatur, mengolah, menyajikan dan menganalisis data angka, agar dapat memberikan gambaran yang teratur, ringkas jelas, mengenai keadaan, peristiwa atau gejala tertentu sehingga dapat ditarik pengertian atau makna tertentu. Statistik deskriptif mengandung informasi mengenai frekuansi, data terkecil, rata-rata, data terbesar, koefisien korelasi antar variabel dan dispersi (Ghozali, 2005).

Lolos uji asumsi klasik menjadi syarat yang harus dipenuhi untuk dapat menjadi model yang baik. Persebaran data yang normal akan memudahkan untuk memprediksi nilai Y sehingga perlu diketahui apakah data yang diteliti berdistribusi normal dengan uji normalitas (Ghozali, 2005). Cara uji yang digunakan untuk penelitian ini adalah uji normalitas kolmogorov-smirnov.

Hubungan linier sempurna atau hampir sempurna antar variabel independen disebut gejala multikolinieritas, sehingga korelasi yang tinggi antar variabel independen akan menganggu hubungan antara variabel bebas dan variabel terikat. Nilai tolerance serta variance inflation factor (VIF) memperlihatkan gejala multikolinieritas. Nilai tolerance lebih dari 0,1 menandakan bebasdari gejala multikolinieritas sedangkan nilai variance inflation factor (VIF) bernilai kurang dari 10 menandakan bahwa variabel independen dalam model dapat dipercaya dan objektif.

Menurut Ghozali (2005), kesamaan atau perbedaan variance dari residul satu peneliti ke peneliti lainnya dapat dilihat dari uji heteroskedastisitas. Homoskedastisitas terjadi bila variance dari residual 1 pengamat ke pengamat 
lainnya tetap dan bila tidak tetap maka disebut heteroskedastisitas. Data tergolong baik tentu harus memiliki kesamaan variance dengan setiap peneliti.

Terjadinya atau tidak terjadinya korelasi data antar deretan waktu bisa dilihat melalui uji autokorelasi. Model Durbin-Watson dapat digunakan untuk melihat apakah terjadi atau tidak terjadinya korelasi data antar deretan waktu. Kriteria pengujiannya adalah: jika angka DW dibawah -2 berarti terdapat autokorelasi positif, angka DW -2 sampai +2 berarti tidak ada autokorelasi, angka DW di atas +2 berarti terdapat autokorelasi negatif.

Analisis regresi linier berganda menjadi teknik analisis yang cocok diterapkan untuk analisis data dalam penelitian ini. Tipe industri, kepemilikan saham pemerintah, profitabilitas merupakan variabel yang memengaruhi variabel terikat. Sedangkan sustainability reportmerupakan variabel yang dipengaruhi variabel bebas. Adapun persamaan untuk menguji hipotesis secara keseluruhan pada penelitian ini adalah sebagai berikut :

$Y=\alpha+\beta_{1} X_{1}+\beta_{2} X_{2}+\beta_{3} X_{3}+e$

Keterangan:

Y = Pengungkapan Sustainability Report

$\alpha \quad=$ Konstanta

$\beta=$ Koefisien regresi

$\mathrm{X}_{1}=$ Tipe industri

$\mathrm{X}_{2}=$ Kepemilikan saham pemerintah

$\mathrm{X}_{3}=$ Profitabilitas

$e=$ Eror

Pengujian apakah variabel independen dalam model secara serempak atau simultan memengaruhi variabel dependen dapat dilihat dari uji F. Penerapan significance level $0,05(\alpha=0,05)$ artinya bila hasil analisis menunjukkan nilai 
signifikansi kurang dari 0,05 , maka terjadi pengaruh semua varibel independen terhadap variabel dependen dan begitu juga sebaliknya.

Uji stastistik $\mathrm{t}$ digunakan untuk melihat kuatnya satu variabel yang memengaruhi berpengaruh terhadap variabel yang dipengaruhi. Penerapan significance level $0,05(\alpha=5 \%)$, artinya nilai kurang dari 0,05 menandakan bahwa secara parsial variabel independen memiliki pengaruh terhadap variabel dependen dan begitu sebaliknya untuk nilai lebih dari 0,05 .

Pengukuran seberapa kuat kemampuan model untuk menggambarkan variasi dari variabel dependen dapat dilihat dari koefisien determinasi $\left(\mathrm{R}^{2}\right)$. Semakin nilai koefisien determinasi yang biasanya menggunakan nilai adjusted $r$ square mendekati 1 maka semakin kuat model menerangkan variasi dari variabel dependen dan begitu juga sebaliknya (Ghozali, 2005).

\section{HASIL DAN PEMBASAHAN}

Populasi dalam penelitian ini adalah perusahaan yang listing di Bursa Efek Indonesia tahun 2013-2016. Sampel yang diperoleh dalam penelitian ini sebanyak 12 perusahaan dengan total data 48 selama empat tahun. Pengumpulan data didapat dari Bursa Efek Indonesia dan situs resmi perusahaan yang menjadi sampel. Penelitian ini berfokus untuk melihat pengaruh tipe industri, kepemilikan saham pemerintah, profitabilitas terhadap sustainability report.

Proses seleksi sampel berdasarkan kriteria yang telah ditetapkan dan ditampilkan pada Tabel 1 berikut. 


\section{Tabel 1}

\section{Proses Seleksi Sampel Berdasarkan Kriteria}

Perusahaan yang terdaftar di BEI

Perusahaan yang tidak mempublikasikan SR

Perusahaan yang sahamnya tidak dimiliki oleh pemerintah

Perusahaan yang selama periode pengamatan tidak mempublikasikan SR Jumlah perusahaan sampel

Tahun Pengamatan

4

Jumlah sampel

Sumber: www.idx.co.id, 2018

Nilai tertinggi, nilai terendah, nilai rata-rata dan standar deviasi disajikan pada hasil statistik deskriptif dari masing-masing variabel penelitian, Tabel 2 menunjukkan jumlah yang diamati dan keempat nilai diatas.

\section{Tabel 2}

Hasil Statistik Deskriptif

\begin{tabular}{lccccc}
\hline \multicolumn{1}{c}{ Variabel } & N & Min. & Maks. & Mean & $\begin{array}{c}\text { Std. } \\
\text { Deviation }\end{array}$ \\
\hline Tipe Industri & 48 & 0,000 & 1,000 & 0,417 & 0,498 \\
$\begin{array}{l}\text { Kepemilikan } \\
\text { Saham }\end{array}$ & 48 & 51,000 & 70,000 & 60,491 & 5,685 \\
$\begin{array}{l}\text { Pemerintah } \\
\text { Profitabilitas }\end{array}$ & 48 & 0,350 & 46,100 & 17,636 & 9,450 \\
$\begin{array}{l}\text { Pengungkapan } \\
\text { Sustainability }\end{array}$ & 48 & 0,088 & 0,978 & 0,399 & 0,206 \\
Report & & & & & \\
\hline
\end{tabular}

Sumber: Data diolah, 2018

Berdasarkan Tabel 2 hasil statistik deskriptif terhadap sustainability reportnilai terendah yang dimiliki sebesar 0,088 , nilai tertinggi yang dimiliki sebesar 0,978, dan nilai rata-rata yang dimiliki sebesar 0,399, serta nilai standar deviasi yang dimiliki sebesar 0,206. Variabel tipe industri memiliki nilai terendah sebesar 0,000 dan nilai tertingginya sebesar 1,000, nilai rata-ratanya sebesar 0,417 
K. Baba Adiatma dan I Ketut Suryanawa. Pengaruh...

dan nilai standar deviasinya sebesar 0,498. Variabel kepemilikan saham pemerintah memiliki nilai terendah sebesar 51,000, nilai tertinggi sebesar 70,000, nilai rata-rata yang dimiliki sebesar 60,491 dan nilai standar deviasi yang dimiliki sebesar 5,685. Variabel profitabilitas memiliki nilai terrendah sebesar 0,350, nilai tertinggi sebesar 46,100, nilai rata-rata yang dimiliki sebesar 17,636 dan nilai standar deviasi yang dimiliki sebesar 9,450.

Persyaratan yang harus dipenuhi untuk melakukan pengujian persamaan regresi berganda yakni memenuhi asumsi klasik. Pada Tabel 3, dapat dikatakan bahwa data berdistribusi normal karena nilai signifikansi yang tertera 0,083 dan melebihi nilai 0,05 .

Tabel 3

Hasil Uji Normalitas

\begin{tabular}{ccc}
\hline Model Regresi & $\begin{array}{c}\text { Asymp. Sig. } \\
\text { (2-tailed) }\end{array}$ & Keterangan \\
\hline $\mathrm{Y}=\alpha+\beta 1 \mathrm{X} 1+\beta 2 \mathrm{X} 2+\beta 3 \mathrm{X} 3+\mathrm{e}$ & 0,083 & Normal \\
\hline Sumber: Data diolah, 2018 & &
\end{tabular}

Hasil uji multikolinieritas ditunjukkan pada Tabel 4, dapat dilihat hasil nilai VIF dan tolerance dari semua variabel independen memenuhi syarat untuk terbebas dari gejala multikolineritas.

Tabel 4

Hasil Uji Multikolinieritas

\begin{tabular}{lcc}
\hline \multicolumn{1}{c}{ Variabel } & Tolerance & VIF \\
\hline Tipe Industri & 0,655 & 1,526 \\
Kepemilikan Saham Pemerintah & 0,579 & 1,726 \\
Profitabilitas & 0,819 & 1,221 \\
\hline Sumber: Data diolah, 2018 & &
\end{tabular}


Hasil uji heteroskedastisitas pada Tabel 5 menunjukkan bahwa data memiliki level signifikan lebih besar dari 0,05 sehingga penelitian ini tidak terdapat gejala heteroskedastisitas.

Tabel 5

Hasil Uji Heteroskedastisitas

\begin{tabular}{lc}
\hline \multicolumn{1}{c}{ Variabel } & Sig. \\
\hline Tipe Industri & 0,270 \\
Kepemilikan Saham Pemerintah & 0,524 \\
Profitabilitas & 0,945 \\
\hline Sumber: Data diolah, 2018
\end{tabular}

Berdasarkan hasil uji autokorelasi yang ditunjukkan pada Tabel 6 dapat disimpulkan bahwa nilai terletak diantara nilai -2 dan +2 ini berarti model terbebas dari gejala auto korelasi.

Tabel 6 Hasil Uji Autokorelasi

\begin{tabular}{lc}
\hline Model Regresi & Durbin Watson \\
\hline $\mathrm{Y}=\alpha+\beta_{1} \mathrm{X}_{1}+\beta_{2} \mathrm{X}_{2}+\beta_{3} \mathrm{X}_{3}+e$ & 1,651 \\
& \\
\hline Sumber: Data diolah, 2018 &
\end{tabular}

Hubungan fungsional antara variabel independen dengan variabel dependen dinyatakan dengan model analisis regresi linier berganda. Analisis regresi linier berganda dilakukan dengan aplikasi program IBM SPSS 23. 
Tabel 7

Hasil Uji Regresi Linier Berganda

\begin{tabular}{|c|c|c|c|}
\hline Model & $\begin{array}{l}\text { Unstandardized } \\
\text { Coefficients }(B)\end{array}$ & Probabilitas (Sig.) & $\begin{array}{l}\text { Hasil Uji } \\
\text { Hipotesis }\end{array}$ \\
\hline Constant & 0,512 & 0,212 & \\
\hline Tipe Industri & 0,222 & 0,003 & Diterima \\
\hline Kepemilikan Saham Pemerintah & $-0,004$ & 0,573 & Ditolak \\
\hline Profitabilitas & 0,001 & 0,724 & Ditolak \\
\hline \multicolumn{4}{|l|}{ Adjusted $R^{2}=0,163$} \\
\hline \multicolumn{4}{|l|}{$\mathrm{F}=4,045($ Sig. $=0,013)$} \\
\hline Dependent Variabel: & \multicolumn{3}{|c|}{ Sustainability Report } \\
\hline
\end{tabular}

Sumber: Data diolah, 2018

Persamaan yang dapat dibuat dari hasil uji regresi linier berganda pada

Tabel 7 adalah sebagai berikut:

$$
\mathrm{Y}=0,512+0,222\left(\mathrm{X}_{1}\right)-0,004\left(\mathrm{X}_{2}\right)+0,001\left(\mathrm{X}_{3}\right)
$$

Angka yang tertera dalam persamaan tersebut dijelaskan sebagai berikut.

Nilai konstanta yang dihasilkan dalam uji regresi berganda tersebut adalah 0,512. Nilai tersebut menunjukkan jika variabel independen bernilai nol maka besarnya kandungan informasi sustainability report sebesar 0,512 atau 51,2\% .

Tipe industri memiliki nilai koefisien 0,222 , artinya jika terjadi kenaikan satu satuan tipe industri akan menambah kandungan informasi dalam sustainability report sebesar 0,222 atau $22,2 \%$.

Nilai koefisien regresi varibel kepemilikan saham pemerintah sebesar -0,004. Ini berarti setiap kenaikan satu satuan kepemilikan saham pemerintah akan menurunkan kandungan informasi sustainability report sebesar 0,004 atau 0,4\%. 
Profitabilitas mempunyai nilai koefisien sebesar 0,001. Ini berarti bahwa setiap kenaikan satu satuan profitabilitas akan menaikan kandungan informasi sustainability report sebesar 0,001 atau 0,1\%.

Berdasarkan Tabel 7 menunjukkan hasil uji F memiliki nilai 4,045 dan nilai signifikan 0,013, ini menunjukkan bahwa nilai signifikan lebih kecil dari 0,05. Dapat diambil kesimpulan bahwa dengan tingkat $\alpha$ (alfa) 0,05 atau 5\%, maka $\mathrm{H}_{0}$ berhasil ditolak dan $\mathrm{H} 1$ diterima yang artinya tipe industri, kepemilikan saham pemerintah, profitabilitas secara bersama-sama (simultan) berpengaruh positif terhadap sustainability report.

Hasil uji koefisien determinasi memiliki nilai adjusted $\mathrm{R}$ atau $\mathrm{R}^{2}$ sebesar 0,163 yang ditunjukkan pada Tabel 7 . Ini artinya variabilitas variabel dependen yang dapat dijelaskan oleh variabel independen sebesar 16,3\%, sisanya dijelaskan oleh variabel lain yang tidak diteliti dalam penelitian ini.

Merujuk pada hasil analisis menunjukkan bahwa hipotesis pertama $\left(\mathrm{H}_{1}\right)$ diterima yang berarti tipe industri memiliki pengaruh positif secara signifikan terhadap sustainability report. Hal ini dapat dilihat dari nilai signifikansinya sebesar 0,003 lebih kecil dari 0,05 dan juga dapat dilihat dari nilai $\beta$ positif sebesar 0,222. Dari persamaan $\mathrm{Y}=0,512+0,222\left(\mathrm{X}_{1}\right)-0,004\left(\mathrm{X}_{2}\right)+0,001\left(\mathrm{X}_{3}\right)$, dapat dilihat bahwa lebih kuat pengaruh tipe industri high profile yang memiliki skor 1 terhadap Y dibandingkan dengan tipe industri low profile yang memiliki skor 0 dengan asumsi bahwa $\mathrm{X}_{2}$ dan $\mathrm{X}_{3}$ sama dengan 0 .

Perusahaan tergolong industri high profilecenderung memiliki aktivitas ekonomi mengolah lingkungan sehingga perlu untuk mempublikasikan informasi 
lebih banyak mengenai tanggung jawab lingkungan dari pada industri lain. Perusahaan bertipe high profile merupakan perusahaan yang mempunyai tingkat sensitivitas yang tinggi terhadap lingkungan, tingkat risiko politik yang tinggi atau tingkat kompetisi yang ketat. Industri perminyakan, tembakau dan rokok, transportasi, penerbangan, agrobisnis, makanan dan minuman, pertambangan, hutan, kertas, kimia, otomotif, media dan komunikasi, kesehatan, pariwisata digolongkan ke dalam tipe industri high profile. Sedangkan perusahaan yang berorientasi pelanggan merupakan ciri khas industri low profile juga diharapkan mampu meningkatkan kandungan informasi tentang tanggung jawab sosialnya kepada stakeholder dalam bentuk sustainability report. Perusahaan property, produk tekstil, rumah tanggabangunan, perbankan, supplier peralatan medis digolongkan ke dalam tipe low profie.

Ciri khas perusahaan high profile adalah kelalaian yang disebabkan aktivitasnya memiliki akibat fatal terhadap masyarakat dan lingkungan sehingga masyarakat lebih menaruh perhatian pada perusahaan tipe ini. Perhatian tersebut akan menjadi tekanan agar aktivitas perusahaan berjalan selaras dengan normanorma yang berlaku pada masyarakat sehingga penyampaian informasi mengenai keselarasan dari sisi ekonomi, sosial dan lingukangan perusahaan tersampaikan dengan baik maka perlunya publikasi sustainability report yang memuat hal tersebut. Manfaat yang diharapkan dari transparasi aktivitas tersebut ialah terjaganya kepercayaan stakeholder dan penciptaan image yang baik bagi perusahaan. 
Terjadinya pengaruh tipe industri terhadap sustainability reportjuga sebelumnya sudah dihasilkan dalam penelitian Zulfi (2010). Jumlah perusahaan yang bertipe high dan low hampir berimbang dalam penelitian ini sehingga dapat mendukung hasil penelitian ini. Masyarakat yang menaruh perhatian lebih pada perusahaan (high)sehingga menjadi tekanan kepada perusahaan untuk melakukan publikasi lebih banyak kandungan informasi dalam sustainability report

Sampel penelitian ini 42 persen merupakan perusahaan high profile yang secara konsisten mengungkapkan sustainability report meskipun ada sedikit yang tidak konsisten dalam pengungkapannya. Sedangkan sisanya 58 persen merupakan perusahaan yang low profile cenderung lebih rendah dari pengungkapan perusahaan yang tergolong high profile. Komposisi yang berimbang dalam sampel mungkin dapat dijadikan alasan dalam hasil penelitian ini.

Berdasarkan hasil analisis statistik ditemukan bahwa hipotesis kedua ditolak. hal ini dapat dilihat dari nilai signifikansi sebesar $0,573>0,05$ dan nilai $\beta$ sebesar 0,04 dengan arah negatif. Hasil tersebut menandakan bahwa kepemilikan saham pemerintah tidak berpengaruh secara signifikan terhadap sustainability report.

Hasil penelitian ini tidak sejalan dengan hasil penelitian (Karina dan Yuyetta, 2013) yang berhasil membuktikan bahwa terdapat pengaruh positif kepemilikan saham pemerintah terhadap pengungkapan tanggung jawab sosial perusahaan. Penyebab hal ini dapat terjadi adalah pemerintah memberikan intervensi kepada pihak manajemen untuk menginformasikan lebih banyak 
K. Baba Adiatma dan I Ketut Suryanawa. Pengaruh...

kandungan informasi dalam sustainability report sebab masyarakat memiliki kepercayaan kepada pemerintah.

Sebagai pemegang saham, kekuatan pemerintah untuk melakukan tekanan kepada manajemen untuk lebih banyak mempublikasi kandungan informasi dalam sustainability report terletak pada jumlah saham perusahaan yang dimiliki pemerintah. Jika pemerintah tergolong dalam pemegang saham prioritas maka pemerintah akan memiliki kemampuan yang kuat untuk berbicara dalam memengaruhi pihak manajemen untuk sesuai dengan kehendak dari pemerintah, namun jika pemerintah hanya sebagai pihak pemegang saham minoritas maka pemerintah memiliki kemampuan yang kecil dan terbatas untuk memengaruhi kebijakan manajemen.

Dukungan stakeholder sangat memengaruhi posisi perusahaan (Chariri \& Nugroho, 2009). Pentingnya dukungan dari stakeholder demi kelangsungan hidup perusahaan membuat perusahaan akan menjaga hubungan baik dengan pihak stakeholder sehingga semua pihak yang terkait dengan perusahaan harus memperoleh kesejahteraan dari perusahaan, sehingga tanggung jawab sosial dari perusahaan tidak hanya fokus kepada pemegang saham saja.

Sampel yang diteliti adalah perusahaan BUMN yang termasuk dalam BEI. Kepemilikan saham pemerintah dalam perusahaan tersebut, semuanya merupakan kepemilikan mayoritas. Proporsi kepemilikan selama periode pengamatan cenderung tidak berubah sedangkan pengungkapan sustainability report setiap tahunnya mengalami perubahan. Hal ini mengindikasikan bahwa ada faktor lain yang lebih mempengaruhi sustainability report sementara itu alasan ini juga 
memperkuat bahwa masih rendahnyakepedulian pemerintah dalam penerapan pembangunan ekonomi berkelanjutan sebagai isu kritis yang harus dilaporkan dalam laporan tahunan. Kemungkinan besar hal tersebut menjadi alasan penelitian ini mendapat hasil di atas.

Berdasarkan hasil analisis statistik dinyatakan bahwa hipotesis ketiga ditolak. dasar dari hasil tersebut dapat dilihat dari nilai siginifikansinya sebesar $0,724>0,05$ sedangkan nilai $\beta$ sebesar 0,01 . Nilai tersebut menunjukkan bahwa profitabilitas tidak berpengaruh secara signifikan terhadap sustainability report.

Tidak terjadinya pengaruh profitabilitas terhadap sustainability report juga telah ditemukan juga oleh peneliti terdahulu yakni (Sembiring (2005)dan Wijaya (2012),hanya saja variabel Y yang mereka gunakan adalah pengungkapan tanggung jawab sosial perusahaan. Perusahaan yang mempunyai ttinggi hanya mementingkan laba semata dalam menjalankan aktivitas bisnis tanpa menghiraukan aktivitas sosial.

Manajemen beranggapan bahwa informasi dapat menganggu baiknya keuangan perusahaan tidak perlu dipublikasi. Tanggapan yang terbalik terjadi ketika keuangan perusahaan melemah, manajemen menganggap bahwa perlu menginformasikan aktivitas sosial dan lingkungan sebagai good news.

Publikasi sustainability report dirasa akan memberikan kerugian oleh manajemen sebab tidak akan memberikan kompensasi. Manajemen merasa menginformasikan tentang aktivitas sosial dan lingkungan malah memberikan kerugian dari segi kompetisi (competitive disadvantage) sebab perusahaan harus menambah biaya. 
K. Baba Adiatma dan I Ketut Suryanawa. Pengaruh...

Pemerintah telah mewajibkan untuk melaksanakan pembangunan ekonomi berkelanjutan guna meningkatkan kualitas kehidupan dan lingkungan yang bermanfaat, baik bagi perseroan sendiri, komunitas setempat, maupun masyarakat pada umumnya melalui Pasal 74 UU Nomor 40 Tahun 2007 tentang Perseroan Terbatas. Peraturan lain adalah pasal 15 huruf b UU 25/2007 yang menyatakan bahwa tanggung jawab yang melekat pada setiap perusahaan penanam modal untuk tetap menciptakan hubungan yang serasi, seimbang, dan sesuai dengan lingkungan, nilai, norma, dan budaya masyarakat setempat. Jika tidak melaksanakan aturan tersebut penanam modal dapat dikenai sanksi berdasarkan Pasal 34 UU 25/2007 berupa peringatan tertulis, pembatasan kegiatan usaha, pembekuan kegiatan usaha dan/atau fasilitas penanam modal atau pencabutan kegiatan usaha dan/atau fasilitas penanam modal. Maka dari itu argumen tersebut menjadi alasan mengapa hasil tersebut didapat dalam penelitian ini.

\section{SIMPULAN}

Berdasarkan hasil analisis statistik dapat disimpulkan hasil penellitian ini bahwa: a) sustainability report secara signifikan dipengaruhi oleh tipe industri pada perusahaan yang terdaftar di BEI pada tahun 2013-2016. b) kepemilikan saham pemerintah tidak berpengaruh terhadap sustainability report pada perusahaan yang terdaftar di BEI pada tahun 2013-2016. c) profitabilitas tidak berpengaruh terhadap sustainability report pada perusahaan yang terdaftar di BEI pada tahun 2013-2016.

Berdasarkan hasil penelitian yang telah disajikan di atas maka dapat diberikan saran sebagai berikut: a) bagi peneliti selanjutnya dianjurkan untuk 
menambahkan variabel lain, mengingat hanya 16,3 persen saja pengaruh variabel bebas dalam penelitian ini, misalnya umur perusahaan dan ukuran perusahaan. b) bagi stakeholder dan pemerintah sebaiknya lebih meningkatkan kesadaran untuk mendorong perusahaan dalam sustainability report. c) bagi perusahaan sebaiknya meningkatkan informasi sustainability report karena mengendalikan risiko terhadap keberlanjutan perusahaan.

\section{REFERENSI}

Ahmad, F. (2014). Pengaruh Karakteristik Perusahaan Dan Profitabilitas Terhadap Pengungkapan Sustainability Report. Jurnal Akuntansi Dan Keuangan Universitas Negeri Padang.

Amran, A., \& Devi, S. (2008). The impact of government and foreign affiliate influence on corporate social reporting: The case of Malaysia. Managerial Auditing Journal, 23(4), 386-404.

Chariri, A., \& Nugroho, F. A. (2009). Retorika Dalam Pelaporan Corporate Social Responsibility: Analisis Semiotik Atas Sustainability Reporting. Simposiun Nasional Akuntansi, XII(5), 0-23.

Chwastiak, M. (1999). Deconstructing the principal-agent model: A view from the bottom. Critical Perspectives on Accounting, 10(4), 425-441.

Clarkson, M. E. (1995).A Stakeholder Framwork For Analyzing and Evaluating Corporate Sosial Performance.Academy of Management Review, 20(1), 92117.

Deegan, C. (2002). Introduction: The legitimising effect of social and environmental disclosures - a theoretical foundation. Accounting, Auditing \& Accountability Journal, 15(3), 282-311.

Elkington, J. (1997). Cannibals with forks. Cannibals with Forks: The Triple Bottom Line of 21 st centuryThe Triple Bottom Line of 21 st Century, (April), $1-16$.

Elkington, J. (1998). The triple bottom line of 21 st century business Cannibals with forks. Environmental Quality Management, 8(April), 424.

Fahrizqi, A. (2010). Faktor-Faktor Yang Mempengaruhi Pengungkapan Corporate Social Responsibility ( Csr ) Dalam Laporan. 
K. Baba Adiatma dan I Ketut Suryanawa. Pengaruh...

Finch, N. (2005). The motivations for adopting sustainability disclosure. Management, (August), 22.

Freeman, R. E. (2004). The Stakeholder Approach Revisited. Zeitschrift Für Wirtschafts-Und Unternehmensethik, 5(3), 228-241.

Ghozali \& Chariri. (2007). Teori Akuntansi. Semarang: Badan Penerbit Undip.

Gray, R., Kouhy, R., \& Lavers, S. (1995). Corporate social and environmental reporting: a review of the literature and a longitudinal study of UK disclosure. Accounting, Auditing \& Accountability Journal, 8(2), 47-77.

Gray, R., Owen, D., \& Maunders, K. (1988). Corporate Social Reporting: Emerging Trends in Accountability and the Social Contract. Accounting, Auditing \& Accountability Journal, 1(1), 6-20.

Jose, A., \& Lee, S. M. (2007). Environmental reporting of global corporations: A content analysis based on Website disclosures. Journal of Business Ethics, 72(4), 307-321.

Karina, L. A. D., \& Yuyetta, E. N. A. (2013). Analisis Faktor-Faktor Yang Mempengaruhi Pengungkapan Csr. Jurnal Bisnis Dan Ekonomi (JBE), 2 Nomor 2(1), 1-12.

Mangos, N. C., \& Lewis, N. R. (1995). A socio-economic paradigm for analysing managers' accounting choice behaviour. Accounting, Auditing \& Accountability Journal, 8(1), 38-62.

Moir, L. (2009). What do we mean by corporate social responsibility? Corporate Governance, 1(2), 16-22.

Patten, D. M. (1991). Exposure, legitimacy, and social disclosure. Journal of Accounting and Public Policy, 10(4), 297-308.

Roberts, R. (1992). Determinants of corporate social responsibility disclosure: An application of stakeholder theory. Accounting, Organizations and Society, $17(6), 595-612$.

Sanditoso, L., \& Chandra, E. (2012). Pengaruh Profitabilitas, Ukuran Perusahaan, Leverage, Umur Perusahaan, dan Dewan Komisaris Independen dalam Pengungkapan Corporate Social Responsibility. Jurnal Bisnis Dan Akuntansi, 14(1), 17-30.

Sembiring, E. R. (2005). Karakteristik perusahaan dan pengungkapan tanggung jawab sosial: Studi empiris pada perusahaan yang tercatat di Bursa Efek Jakarta. SNA VIII Solo, 15 - 16 September 2005, (September), 15-16. 
Susanto, Y. K., \& Tarigan, J. (2013). Pengaruh Pengungkapan Sustainability Report Terhadap Kinerja Keuangan Perusahaan. Universitas Diponegoro, 6(1), 1-29.

UU Nomor 40 Tahun 2007. Undang-Undang No. 40 Tahun 2007 Tentang PerseroanTerbatas.http://bapepam.go.id/reksadana/files/regulasi/UU40200 7.pdfdiakses tanggal 4 Januari 2018.

Wijaya, M. (2012). Faktor-Faktor Yang Mempengaruhi Pengungkapan Tanggung Jawab Sosial Pada Perusahaan Manufaktur Yang Terdaftar Di Bursa Efek Indonesia. Jurnal Ilmiah Mahasiswa Akuntansi, 1(1), 26-30.

Zulfi, N. M. (2014). Pengaruh Kepemilikan Saham Pemerintah, Tipe Industri, Ukuran Perusahaan, Dan Profitabilitas Terhadap Pengungkapan Corporate Sosial Responsibility Pada Perusahaan Go Public Di Indonesia, (September). 